\title{
Analisis Kadar Protein, Lemak, Dan Total Asam Laktat Dari Fermentasi Kefir Berbahan Baku Kolostrum Sapi
}

\author{
Nurhasanah $^{1 *}$, Siwi Meutia Sadewi ${ }^{1 *}$, R. Supriyato ${ }^{1}$, Aspita Laila $^{1}$ \\ ${ }^{1}$ Jurusan Kimia, FMIPA, Universitas Lampung, Bandar Lampung, 35141 \\ siwimutiasadewi@gmail.com
}

\begin{tabular}{|l|}
\hline Artikel Info \\
Diterima \\
tanggal \\
12.09 .2019 \\
Disetujui \\
publikasi \\
tanggal \\
31.10 .2019 \\
\\
Kata kunci : \\
Fermentasi, \\
Kefir, \\
Kolostrum Sapi, \\
Minuman \\
Probiotik \\
\hline
\end{tabular}

ABSTRAK

Kefir merupakan salah satu minuman probiotik yang baik untuk kesehatan. Kefir dapat dibuat dari susu sapi, susu kambing, ataupun susu kedelai. Pada penelitian ini, kolostrum sapi pemerahan pertama digunakan sebagai bahan baku pembuatan kefir. Penelitian ini bertujuan untuk mengetahui kondisi optimum fermentasi kefir kolostrum sapi dan pengaruh suhu, waktu fermentasi, serta konsentrasi bibit kefir terhadap kadar protein, lemak, dan total asam laktat. Metode yang digunakan pada penelitian ini meliputi analisis protein dengan metode kjedahl, analisis lemak dengan metode sokhletasi dan Babcock, dan analisis total asam laktat dengan metode titrasi. Keseluruhan data yang diperoleh dianalisis menggunakan Anova. Hasil penelitian menunjukkan bahwa kadar protein tertinggi kefir kolostrum sapi adalah pada variasi bibit $10 \%$, suhu $37{ }^{\circ} \mathrm{C}$, dan waktu fermentasi 24 jam yaitu $21,7100 \%$. Kadar lemak terendah pada bibit $10 \%$, suhu $37{ }^{\circ} \mathrm{C}$, dan waktu fermentasi 24 jam yaitu $0,3728 \%$. Kadar total asam laktat tertinggi terdapat pada variasi bibit $10 \%$, suhu $37{ }^{\circ} \mathrm{C}$, dan waktu fermentasi 24 jam yaitu 1,4569\%. Berdasarkan hasil yang diperoleh dapat disimpulkan bahwa adanya variasi waktu fermentasi, suhu fermentasi dan konsentrasi bibit kefir tidak terlalu berpengaruh nyata $(\alpha>0,05)$ terhadap kadar protein, lemak, total asam laktat, dan total bakteri asam laktat pada fermentasi kefir kolostrum sapi.

\section{ABSTRACT}

Kefir is one of the good probiotic drinks for health. Kefir can be made from cow's milk, goat's milk or soy milk. In this research, the first cow milk colostrum was used as raw material for making kefir. The aim of this research was to determine the optimum condition of kefir bovine colostrum fermentation and the effect of temperature, fermentation time, and concentration of kefir seedlings on protein, fat, and total acid. The method used in this study included protein analysis with the kjedahl method, fat analysis with soxhletation and Babcock methods, and total analysis of lactic acid by titration method. Then, all data obtained were analyzed using Anova. The results showed that the highest protein content of kefir cow colostrum was in the variation of $10 \%$ seeds, temperature $37^{\circ} \mathrm{C}$, and 24 hour fermentation time which was $21.7100 \%$. Where as the lowest fat content in the seeds is $10 \%$, the temperature $37{ }^{\circ} \mathrm{C}$, and the fermentation time was 24 hours, which was $0.3728 \%$. The highest total lactic acid levels were found in $10 \%$ seed varieties, $37{ }^{\circ} \mathrm{C}$, and 24 hour fermentation time at $1.4569 \%$. Based on the results, it can be concluded that the variation in fermentation time, fermentation temperature and kefir seed concentration did not significantly influence $(\alpha>0.05)$ on protein, fat, total lactic acid, and total lactic acid bacteria in the kefir fermentation of cow colostrum.

\section{PENDAHULUAN}

Produk olahan pangan di Indonesia telah banyak diketahui dan diproses dengan menggunakan beragam teknik pengolahan. Salah satu teknik pengolahan pangan yang banyak 
dilakukan adalah dengan cara fermentasi (Buckle et al, 1985). Fermentasi adalah pengubahan karbohidrat menjadi alkohol dan karbon dioksida atau asam amino organik menggunakan ragi, bakteri, fungi atau campuran dari ketiganya. Berbagai macam produk fermentasi sudah banyak diketahui, diantaranya seperti kimchi, tape, tempe, tempoyak, termasuk salah satunya adalah fermentasi susu. Produk fermentasi susu merupakan produk olahan berbahan baku susu mengggunakan campuran ragi, bakteri, khamir, atau campuran ketiganya. Produk fermentasi susu saat ini sudah banyak dikenal, diantaranya seperti yogurt dan yakult. Selain dua produk tersebut ada satu produk olahan susu fermentasi yang belum banyak diketahui yaitu kefir. Kefir merupakan salah satu produk fermentasi susu, dimana laktosa dihidrolisis selama proses fermentasi oleh bakteri yang terkandung dalam biji kefir (kefir grain). Kefir memiliki fungsi sebagai minuman probiotik yang baik untuk kesehatan manusia, karena pada saat proses fermentasi berlangsung terbentuk beberapa mikroba seperti bakteri asam laktat, bakteri eksopolisakarida, dan peptida (Pogacic et al, 2013).

Beberapa penelitian melaporkan tentang kandungan serta manfaat menggunakan susu sebagai bahan pembuatan kefir, diantaranya menggunakan susu nabati dari bahan kacangkacangan seperti kacang merah (Kunaepah, 2008), kedelai (Zaini, 2016), susu sapi (Kurniati dkk, 2016), dan ada juga yang menggunakan susu kambing (Martharini dan Indratiningsih, 2017). Selain macam-macam susu tersebut ada juga susu kolostrum yang dapat digunakan sebagai bahan pembuatan kefir. Namun sampai saat ini, belum banyak yang menggunakan kolostrum sebagai bahan baku pembuatan kefir.

Kolostrum merupakan susu pertama yang dihasilkan oleh mamalia setelah melahirkan. Kolostrum mengandung laktalbumin dan laktoprotein, serta mengandung antibodi yang berperan dalam kekebalan tubuh (Godhia dan Patel, 2013). Kolostrum memiliki kandungan biologis aktif seperti asam nukleat dan turunan asam amino, serta memiliki kandungan substansi kimia seperti protein, lemak, vitamin dan mineral yang sangat tinggi pada pemerahan beberapa jam setelah melahirkan (Kielb et al, 2018). Berdasarkan uraian diatas, maka pada penelitian ini akan dilakukan proses optimasi produksi minuman probiotik kefir berbahan baku kolostrum sapi untuk mengetahui kandungan protein, lemak, total asam laktat,dan jumlah bakteri asam laktat. adapun optimasi yang dilakukan meliputi, variasi waktu fermentasi,variasi penambahan bibit kefir serta variasi suhu fermentasi. Adapun variasi waktu fermentasi yang digunakan adalah 24 jam dan 48 jam serta penambahan bibit sebanyak $5 \%$ dan $10 \%$. Sedangkan variasi suhu fermentasi yaitu $27{ }^{\circ} \mathrm{C}$ dan $35{ }^{\circ} \mathrm{C}$. Adanya 
perbedaan starter, waktu fermentasi, dan suhu yang digunakan diduga dapat mempengaruhi kandungan protein, lemak, total asam laktat, dan jumlah bakteri asam laktat.

\section{METODE}

\section{Alat dan Bahan}

Peralatan utama yang digunakan dalam penelitian ini adalah botol kaca, inkubator (Memmert), lemari pendingin, saringan, beaker glass, botol Babcock, seperangkat alat sokhletasi (Buchi), Erlenmeyer, waterbath, sentrifius, seperangkat alat kjedahl (Velp Scientifica), batu didih, cawan petri, colony counter, pipet ukur $1 \mathrm{ml}, 5 \mathrm{ml}$, dan $10 \mathrm{ml}$, autoklaf, dan oven (Memmert).

Adapun bahan-bahan yang digunakan meliputi susu kolostrum sapi pemerahan pertama yang diambil dari PT. Great Giant Livestock Terbanggi Besar Lampung Tengah, bibit kefir, n-heksan, $\mathrm{NaOH} 30 \% \mathrm{~K}_{2} \mathrm{SO}_{4}, \mathrm{CuSO}_{4} .5 \mathrm{H}_{2} \mathrm{O}$, katalis selen, $\mathrm{H}_{2} \mathrm{SO}_{4}$ pekat, indikator pp, $\mathrm{H}_{3} \mathrm{BO}_{3} 4 \%, \mathrm{HCl} 0,1 \mathrm{M}$, aquades, $\mathrm{NaOH} 0,1 \mathrm{~N}$, dan media Man Rogosa and Sharpe (MRS).

\section{Prosedur}

Penelitian ini merupakan penelitian secara eksperimen yang dilakukan untuk mengetahui pengaruh dari lama waktu fermentasi dengan jumlah total asam laktat, bakteri asam laktat, protein, dan lemak didalam susu kefir kolostrum sapi. Penelitian ini menggunakan Rancangan Acak Lengkap (RAL) dengan tiga perlakuan dan tiga kali pengulangan. Data yang diperoleh dianalisis dengan menggunakan analisis sidik ragam (ANOVA).

\section{Pelaksanaan Penelitian}

Penelitian ini meliputi sterilisasi alat, preparasi kolostrum sapi, pembuatan kefir kolostrum sapi, analisis kadar protein, lemak, dan total asam laktat.

\section{Preparasi kolostrum sapi}

Preparasi ini bertujuan untuk mensterilisasi kolostrum sapi agar tidak terkontaminasi oleh mikroba pencemar. Adapun preparasi ini dilakukan dengan cara pasteurisasi pada suhu $70^{\circ} \mathrm{C}$ selama 15 detik. 2,25 L kolostrum sapi dipasteurisasi, kemudian kolostrum dibiarkan pada suhu ruang hingga suhunya mencapai $\pm 27{ }^{\circ} \mathrm{C}$. Selanjutnya diambil 0,25 L kolostrum digunakan langsung untuk analisis kadar protein, lemak, asam laktat awal tanpa difermentasi, $500 \mathrm{ml}$ kolostrum sapi digunakan untuk tahap fermentasi dengan variasi bibit 5\%, waktu 
fermentasi 24 dan 48 jam, dan suhu fermentasi $27{ }^{\circ} \mathrm{C}, 500 \mathrm{ml}$ kolostrum sapi digunakan untuk tahap fermentasi dengan variasi bibit 5\%, waktu fermentasi 24 dan 48 jam, dan suhu fermentasi $37{ }^{\circ} \mathrm{C}, 500 \mathrm{ml}$ kolostrum sapi digunakan untuk tahap fermentasi dengan variasi bibit $10 \%$, waktu fermentasi 24 dan 48 jam, dan suhu fermentasi $27{ }^{\circ} \mathrm{C}, 500 \mathrm{ml}$ kolostrum sapi digunakan untuk tahap fermentasi dengan variasi bibit 10\%, waktu fermentasi 24 dan 48 jam, dan suhu fermentasi $37^{\circ} \mathrm{C}$.

\section{Pembuatan Kefir Kolostrum Sapi}

Pembuatan susu kefir kolostrum dilakukan dengan cara 1 L kolostrum sapi yang telah di pasteurisasi dimasukkan kedalam botol kaca kemudian ditambahkan dengan $5 \%$ bibit kefir. Susu kefir yang dibuat difermentasi pada suhu $27^{\circ} \mathrm{C}$ dan $37^{\circ} \mathrm{C}$ selama 24 jam dan 48 jam. Kemudian kefir yang telah dibuat disimpan pada suhu $4{ }^{\circ} \mathrm{C}$ untuk menghambat laju pertumbuhan bakteri asam laktat dan digunakan untuk pengujian lebih lanjut. Hal ini juga dilakukan pada pembuatan kefir kolostrum sapi dengan bibit $10 \%$.

\section{Analisis Kadar Protein}

Analisis ini bertujuan untuk mengetahui \% kadar protein kasar yang terdapat dalam sampel susu kolostrum dan kefir kolostrum menggunakan metode kjedahl sesuai dengan standar SNI 2981: 2009.

\section{Analisis Kadar Lemak}

Analisis ini bertujuan untuk mengetahui kadar lemak yang terdapat dalam sampel kolostrum dan sampel kefir kolostrum sapi. Analisis kadar lemak dilakukan dengan menggunakan metode Babcock untuk sampel susu kolostrum tanpa fermentasi dan metode sokhletasi digunakan untuk sampel susu kefir kolostrum setelah fermentasi.

\section{Analisis Total Asam Laktat}

Analisis ini bertujuan untuk mengetahui jumlah total asam laktat yang terdapat dalam sampel kefir kolostrum sapi. Analisis total asam dihitung sebagai asam laktat menurut standar SNI 2981: 2009 menggunakan metode titrasi.

\section{HASIL DAN PEMBAHASAN}

\section{Kolostrum Sapi}

Kolostrum merupakan susu pertama yang dihasilkan oleh mamalia setelah melahirkan. Kolostrum mengandung laktalbumin dan laktoprotein, serta mengandung antibodi yang berperan dalam kekebalan tubuh (Godhia dan Patel, 2013). Penelitian ini menggunakan kolostrum sapi sebagai bahan bahan baku pembuatan kefir. Berdasarkan 
pengamatan yang dilakukan, kolostrum sapi memiliki warna lebih kuning dan lebih kental dari susu biasa, adapun gambar dari kolostrum sapi sebelum dilakukan fermentasi dapat dilihat pada Gambar 1.

Tahap analisis awal kadar protein terhadap kolostrum sapi ditentukan dengan menggunakan metode kjedahl dan analisis lemak menggunakan metode Babcock. Adapun persentase kadar protein dan lemak kolostrum sapi dapat dilihat pada Tabel 1.

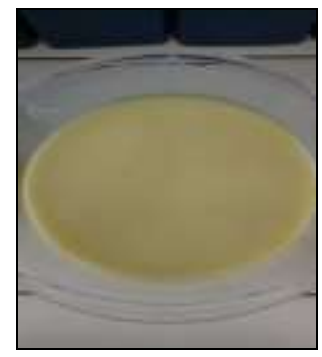

Gambar 1. Kolostrum Sapi

Tabel 1. Kadar Protein Dan Lemak Pada Kolostrum Sapi

\begin{tabular}{llll}
\hline \multirow{2}{*}{ No } & \multicolumn{1}{c}{ Sampel } & Protein & Lemak \\
& & & $(\%)$ \\
\hline 1 & Susu kolostrum U1 & 21,56 & 6,30 \\
2 & Susu kolostrum U2 & 21,59 & 6,30 \\
3 & Susu kolostrum U3 & 21,67 & 6,20 \\
4 & Rata-rata & 21,60 & 6,27 \\
\hline
\end{tabular}

Berdasarkan Tabel 1 tersebut menunjukkan bahwa hasil rata-rata kadar protein pada kolostrum sapi yaitu 21,60\%. Hal ini membuktikan bahwa kadar protein yang dimiliki kolostrum sapi sangat tinggi dibandingkan dengan kadar protein pada susu sapi biasa, begitu juga dengan kadar lemak yang diperoleh rata-rata 6,27\%. Berdasarkan penelitian sebelumnya, dilaporkan bahwa kadar protein pada susu sapi biasa yaitu 3,01-3,59\% dan kadar lemak 1,42-1,96\% (Oka dkk, 2017).

\section{Kefir Kolostrum Sapi}

Kefir kolostrum sapi merupakan salah satu minuman probiotik yang memiliki banyak sekali manfaat untuk kesehatan. Pada penelitian ini telah dibuat kefir kolostrum sapi dengan bahan baku kolostrum sapi hasil pemerahan pertama. Hasil yang diperoleh dari pembuatan kefir 
kolostrum sapi dengan variasi starter kefir, suhu fermentasi, dan waktu fermentasi dapat dilihat pada Gambar 2.

Berdasarkan Gambar 2 terlihat penampakan tekstur dari kefir kolostrum sapi berwarna kuning dan semakin mengental dibandingkan dengan kolostrum sapi sebelum fermentasi. Proses fermentasi yang dilakukan dengan bahan kolostrum sapi pemerahan pertama pada berbagai variasi tidak menunjukkan adanya pemisahan yang terjadi antara whey dan curd yang biasanya terjadi pada fermentasi susu biasa.
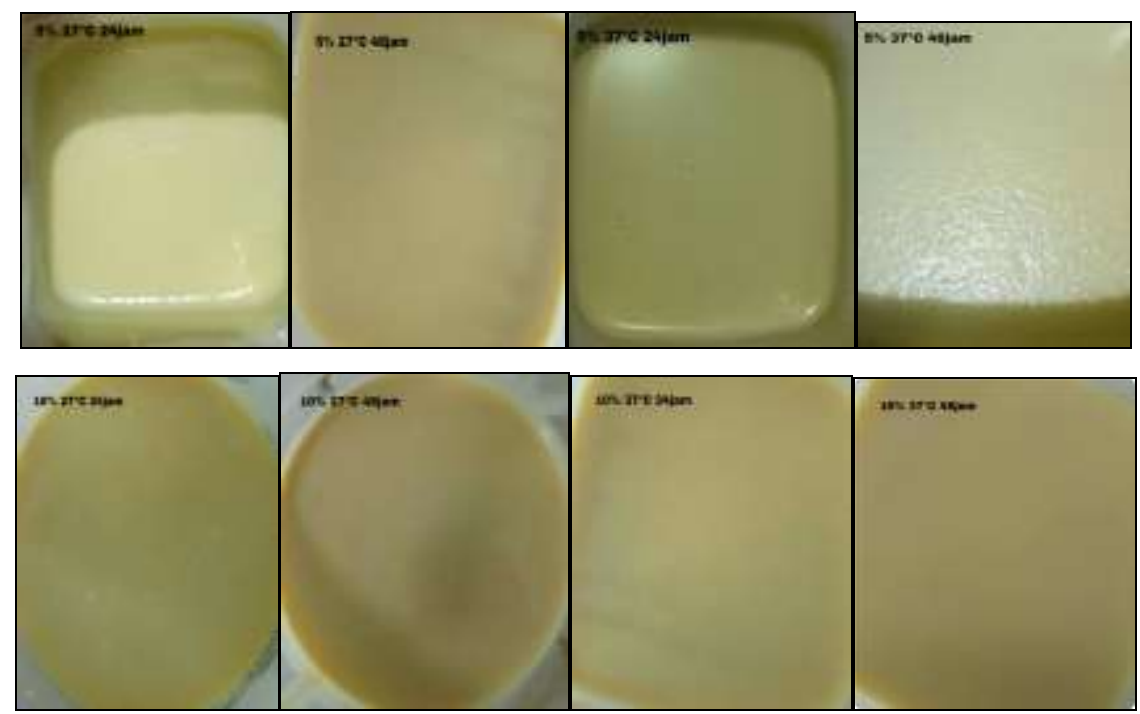

Gambar 2. Hasil Pembuatan Kefir Kolostrum Sapi

\section{Kadar Protein Kefir Kolostrum Sapi}

Protein merupakan salah satu kandungan terpenting yang harus ada didalam minuman probiotik kefir. Pada penelitian ini analisis kadar protein pada kefir kolostrum sapi menggunakan metode kjedahl, Adapun hasil pengujian protein pada kefir kolostrum sapi dengan variasi starter kefir, suhu fermentasi, dan waktu fermentasi dapat dilihat pada Tabel 2 dan 3.

Tabel 2. Kadar Protein Kefir Kolostrum Sapi dengan Bibit 5\%.

\begin{tabular}{cccccc}
\hline \multirow{2}{*}{ Suhu } & \multirow{2}{*}{ Waktu } & \multicolumn{3}{c}{ Pengulangan (\%) } & \multirow{2}{*}{ Rata-rata (\%) } \\
& & I & II & III & \\
\hline \multirow{2}{*}{$27^{\circ} \mathrm{C}$} & 24 jam & 19,7253 & 20,1320 & 20,2741 & 20,1320 \\
& 48 jam & 20,3644 & 20,1398 & 20,3834 & 20,1398 \\
\multirow{2}{*}{$37^{\circ} \mathrm{C}$} & 24 jam & 20,8138 & 20,3447 & 20,2156 & 20,3447 \\
& 48 jam & 20,4649 & 20,3748 & 20,2480 & 20,3748 \\
\hline
\end{tabular}


Tabel 3. Kadar Protein Kefir Kolostrum Sapi dengan Bibit 10\%.

\begin{tabular}{|c|c|c|c|c|c|}
\hline \multirow{2}{*}{ Suhu } & \multirow{2}{*}{ Waktu } & \multicolumn{3}{|c|}{ Pengulangan (\%) } & \multirow{2}{*}{ Rata-rata (\%) } \\
\hline & & I & II & III & \\
\hline \multirow{2}{*}{$27^{\circ} \mathrm{C}$} & 24 jam & 20,0236 & 19,9771 & 20,2069 & 20,0692 \\
\hline & $48 \mathrm{jam}$ & 20,0589 & 21,0803 & 20,2336 & 20,4576 \\
\hline \multirow{2}{*}{$37^{\circ} \mathrm{C}$} & 24 jam & 20,9817 & 22,4282 & 21,7202 & 21,7100 \\
\hline & 48 jam & 19,9253 & 20,8219 & 20,7513 & 20,4995 \\
\hline
\end{tabular}

Berdasarkan Tabel 2 diketahui bahwa kadar protein tertinggi pada fermentasi kefir menggunakan bibit $5 \%$ yaitu di suhu $37^{\circ} \mathrm{C} 48$ jam yaitu 20,3748\%. Sedangkan pada Tabel 3 dapat diketahui bahwa kadar protein tertinggi pada fermentasi kefir menggunakan bibit 10\% yaitu di suhu $37^{\circ} \mathrm{C}$ selama 24 jam yaitu $21,7100 \%$. Hasil dari penelitian ini menunjukkan bahwa kadar kefir kolostrum sapi masih memenuhi syarat rentang kadar protein menurut standar internasional (CODEX STAND 243-2003) yaitu komposisi protein kefir minimal 2,7\%. Adapun grafik hasil pengujian kadar protein pada kefir kolostrum sapi dapat dilihat pada Gambar 3.

Berdasarkan Gambar 3 terlihat adanya penurunan kadar protein setelah fermentasi dibandingkan dengan sebelum fermentasi dengan adanya variasi waktu, suhu, dan bibit kefir. Hal ini diduga protein dari senyawa kompleks yang terdapat pada kolostrum terdenaturasi menjadi senyawa yang lebih sederhana dengan bantuan enzim protease yang disekresi oleh mikroba yang terjadi pada saat fermentasi, sehingga kadar protein dari kolostrum tersebut saat di fermentasi akan sedikit menurun (Nihayah, 2015). Namun pada penambahan bibit $10 \%$ dengan suhu $37^{\circ} \mathrm{C}$ dan lama fermentasi 24 jam ada sedikit kenaikan kadar protein, disebabkan karena susu merupakan sumber energi dan karbon bagi pertumbuhan bakteri, sehingga semakin banyak jumlah bakteri, semakin tinggi kadar protein minuman susu fermentasi, karena sebagian besar komponen penyusun bakteri adalah protein (Herawati dan Wibawa, 2009).

Berdasarkan analisis data varian (ANOVA) diperoleh nilai $(\alpha>0,05)$ hal ini membuktikan bahwa variasi waktu fermentasi, suhu fermentasi, dan bibit kefir tidak berpengaruh nyata terhadap kandungan dari protein kefir. Hal ini dikarenakan kandungan protein dari kolostrum sendiri sudah sangat tinggi. Berbeda dengan kefir yang menggunakan susu sapi biasa sebagai bahan baku pembuatan kefir, dimana variasi waktu dan bibit sangat berpengaruh (Kurniati dkk, 2016). 


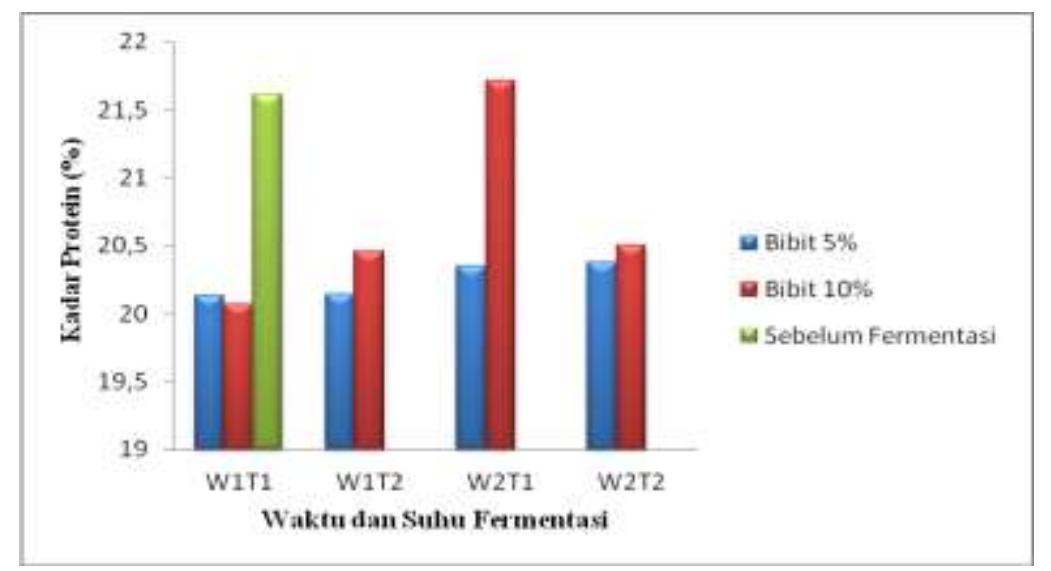

Gambar 3. Grafik hasil analisis protein kefir kolostrum sapi dengan bibit 5\% dan $10 \%$.

\section{Kadar Lemak Kefir Kolostrun Sapi}

Kadar lemak merupakan salah satu parameter penentu kualitas bahan pangan salah satunya kefir. Pada penelitian ini telah dilakukan analisis kandungan lemak pada kefir kolostrum sapi menggunakan metode sokhletasi. Pada penentuan lemak kefir kolostrum sapi menggunakan metode sokhletasi dikarenakan sampel kefir kolostrum sapi memiliki tekstur lebih kental dari kolostrum sebelum difermentasi, sehingga sulit untuk dilakukan dengan metode Babcock dan untuk menjaga ke akuratan pada penelitian maka digunakan metode sokhletasi. Data hasil pengujian lemak pada kefir kolostrum sapi dengan variasi starter kefir, suhu fermentasi, dan waktu fermentasi dapat dilihat pada Tabel 4 dan 5.

Tabel 4. Kadar Lemak Kefir Kolostrum Sapi dengan Bibit 5\%.

\begin{tabular}{cccccc}
\hline \multirow{2}{*}{ Suhu } & \multirow{2}{*}{ Waktu } & \multicolumn{3}{c}{ Pengulangan (\%) } & \multirow{2}{*}{ Rata-rata (\%) } \\
& & I & II & III & \\
\hline \multirow{2}{*}{$27^{\circ} \mathrm{C}$} & 24 jam & 0,5882 & 0,5762 & 0,6942 & 0,6195 \\
& 48 jam & 1,2365 & 1,2123 & 1,3216 & 1,2568 \\
$377^{\circ} \mathrm{C}$ & 24 jam & 1,3534 & 1,2894 & 1,4987 & 1,3805 \\
& 48 jam & 4,322 & 4,4319 & 4,2801 & 4,3447 \\
\hline
\end{tabular}

Tabel 5. Kadar Lemak Kefir Kolostrum Sapi dengan Bibit $10 \%$.

\begin{tabular}{cccccc}
\hline \multirow{2}{*}{ Suhu } & \multirow{2}{*}{ Waktu } & \multicolumn{3}{c}{ Pengulangan (\%) } & Rata-rata (\%) \\
& & I & II & III & 0,4545 \\
\multirow{2}{*}{$27^{\circ} \mathrm{C}$} & 24 jam & 0,4800 & 0,3833 & 0,5001 & 1,5507 \\
& 48 jam & 1,7447 & 1,3364 & 1,5711 & 0,3728 \\
$377^{\circ} \mathrm{C}$ & 24 jam & 0,3189 & 0,3387 & 0,4607 & 0,7226 \\
\hline
\end{tabular}


Berdasarkan Tabel 4 dapat diketahui bahwa kadar lemak tertinggi pada fermentasi kefir kolostrum sapi menggunakan bibit $5 \%$ yaitu di suhu $37^{\circ} \mathrm{C}, 48$ jam dengan kadar 4,3447\%. Sedangkan pada Tabel 5 dapat diketahui bahwa kadar lemak tertinggi pada fermentasi kefir kolostrum sapi menggunakan bibit $10 \%$ yaitu di suhu $27^{\circ} \mathrm{C} 48$ jam dengan kadar 1,5507\%. Data pada Tabel 4 dan 5 menunjukkan bahwa kadar lemak kefir pada penelitian ini sesuai dengan standar internasional (CODEX STAND 243-2003) yaitu kadar lemak kefir yaitu kurang dari $10 \%$. Hasil yang diperoleh ini menunjukkan bahwa adanya penurunan kandungan lemak kolostrum sapi sebelum dan sesudah fermentasi. Adapun grafik hasil pengujian kadar lemak kefir kolostrum sapi dengan berbagai variasi dapat dilihat pada Gambar 4.

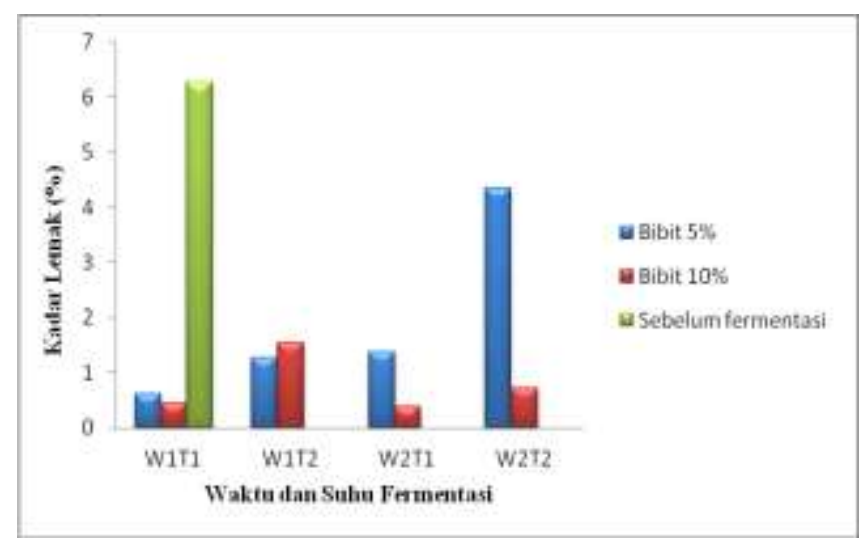

Gambar 4. Grafik hasil analisis lemak kefir kolostrum sapi dengan bibit 5\% dan $10 \%$.

Berdasarkan grafik pada Gambar 6 menunjukkan bahwa semakin tinggi konsentrasi bibit kefir, maka kadar lemak akan semakin rendah. Hal ini dikarenakan bakteri dari bibit kefir akan menghasilkan enzim lipase. Semakin banyak pertumbuhan bakteri dalam susu, maka pertumbuhan enzim lipase akan semakin banyak, sehingga lemak yang terhidrolisis semakin banyak dan kadar lemak yang terkandung didalamnya akan menurun (Nihayah, 2015). Berdasarkan analisis data varian (ANOVA) diperoleh nilai $(\alpha>0,05)$ hal ini membuktikan bahwa variasi waktu fermentasi, suhu fermentasi, dan bibit kefir tidak berpengaruh nyata terhadap kandungan dari lemak kefir.

\section{Kadar Total Asam Laktat Kefir Kolostrum Sapi}

Pada penelitian ini juga dilakukan analisis kadar total asam laktat pada kefir kolostrum sapi. Tahap ini dilakukan dengan tujuan untuk mengetahui total asam laktat dengan menggunakan metode titrasi. Adapun data hasil pengujian total asam laktat pada kefir 
kolostrum sapi dengan variasi starter kefir, suhu fermentasi, dan waktu fermentasi dapat dilihat pada Tabel 6 dan 7.

Tabel 6. Kadar Total Asam Laktat Kefir Kolostrum Sapi dengan Bibit 5\%

\begin{tabular}{cccccc}
\hline \multirow{2}{*}{ Suhu } & \multirow{2}{*}{ Waktu } & \multicolumn{3}{c}{ Pengulangan (\%) } & Rata-rata (\%) \\
\hline \multirow{2}{*}{$27^{\circ} \mathrm{C}$} & 24 jam & 0,8856 & 0,8769 & 0,8944 & 0,8856 \\
& 48 jam & 0,9521 & 0,8331 & 0,8728 & 0,8860 \\
\multirow{2}{*}{$37^{\circ} \mathrm{C}$} & 24 jam & 0,9881 & 1,0779 & 0,1228 & 1,0629 \\
& 48 jam & 0,9620 & 0,9620 & 0,9780 & 0,9673 \\
\hline
\end{tabular}

Tabel 7. Kadar Total Asam Laktat Kefir Kolostrum Sapi dengan Bibit 10\%

\begin{tabular}{|c|c|c|c|c|c|}
\hline \multirow{2}{*}{ Suhu } & \multirow{2}{*}{ Waktu } & \multicolumn{3}{|c|}{ Pengulangan (\%) } & \multirow{2}{*}{ Rata-rata $(\%)$} \\
\hline & & I & II & III & \\
\hline \multirow{2}{*}{$27^{\circ} \mathrm{C}$} & 24 jam & 1,1150 & 1,1579 & 1,2008 & 1,1579 \\
\hline & 48 jam & 1,1240 & 1,0491 & 1,0865 & 1,0865 \\
\hline \multirow{2}{*}{$37^{\circ} \mathrm{C}$} & 24 jam & 1,4175 & 1,4963 & 1,4569 & 1,4569 \\
\hline & 48 jam & 0,3983 & 0,3540 & 0,4426 & 0,3983 \\
\hline
\end{tabular}

Berdasarkan Tabel 6 dapat diketahui bahwa kadar total asam laktat tertinggi pada fermentasi kefir kolostrum sapi menggunakan bibit 5\% yaitu di suhu $37^{\circ} \mathrm{C} 24$ jam dengan kadar $1,0629 \%$. Sedangkan pada Tabel 7 dapat diketahui bahwa kadar total asam laktat tertinggi pada fermentasi kefir kolostrum sapi menggunakan bibit $10 \%$ yaitu di suhu $37^{\circ} \mathrm{C}$ selama 24 jam denagn kadar 1,4569\%. Hasil pada Tabel 6 dan 7 menunjukkan bahwa kadar total asam laktat kefir kolostrum sapi pada penelitian ini sesuai dengan standar internasional (CODEX STAND 243-2003) yaitu minimal 0,6\%. Adapun grafik penentuan kadar total asam laktat pada kefir kolostrum sapi dapat dilihat pada Gambar 5.

Penggunaan konsentrasi bibit yang tinggi akan menghasilkan kadar asam laktat yang tinggi pula karena adanya kerja mikroorganisme (Agustina dkk, 2013). Kadar asam laktat mempengaruhi kadar dari laktosa, semakin tinggi kadar asam laktat maka bakteri asam laktat yang terkandung akan semakin tinggi dan laktosa akan semakin rendah atau cenderung menurun (Umam dkk, 2012). Hal inilah yang membuktikan bahwa kefir sangat bermanfaat bagi penderita lactose intolerant. Berdasarkan analisis data varian (ANOVA) diperoleh nilai $(\alpha>0,05)$ hal ini membuktikan bahwa variasi waktu fermentasi, suhu fermentasi, dan bibit kefir tidak berpengaruh nyata terhadap kadar total asam laktat kefir. Hasil ini berbeda dengan 
penelitian Kurniati dkk, 2016 yang memggunakan susu sapi biasa dalam pembuatan kefir dengan variasi bibit dan waktu fermentasi menghasikanl data anova yang berpengaruh nyata terhadap kadar total asam laktat.

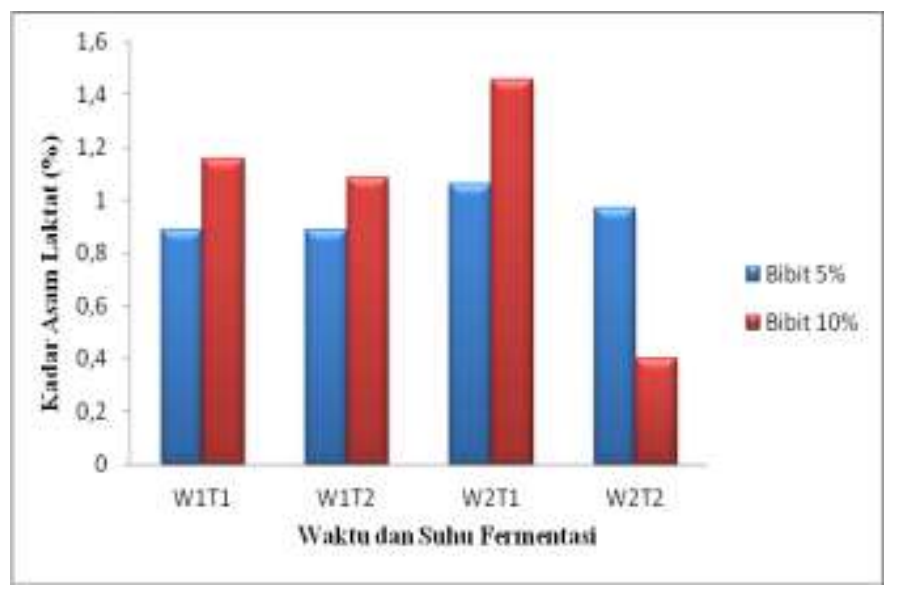

Gambar 5. Grafik kadar total asam laktat kefir kolostrum sapi dengan bibit 5\%.dan $10 \%$.

\section{KESIMPULAN}

Kadar protein tertinggi pada kefir kolostrum sapi adalah pada variasi bibit 10\%, suhu $37^{\circ} \mathrm{C}$, dan lama fermentasi 24 jam yaitu 21,7100\%. Kadar lemak terendah pada kefir kolostrum sapi dengan variasi bibit $10 \%$, suhu $37^{\circ} \mathrm{C}$, dan lama fermentasi 24 jam yaitu $0,3728 \%$. Kadar total asam laktat tertinggi pada kefir kolostrum sapi terdapat pada variasi bibit $10 \%$, suhu $37^{\circ} \mathrm{C}$, dan lama fermentasi 24 jam yaitu 1,4569\%. Hasil analisis anova dengan variasi waktu fermentasi, suhu fermentasi dan konsentrasi bibit kefir tidak terlalu berpengaruh nyata $(\alpha>0,05)$ terhadap kadar protein, lemak, total asam laktat, dan total bakteri asam laktat pada fermentasi kefir kolostrum sapi.

\section{DAFTAR PUSTAKA}

Agustina, L., Triana, S., dan Triana, Y.A., 2013. Penggunaan Starter Biji Kefir Dengan Konsentrasi Yang Berbeda Pada Susu Sapi Terhadap PH dan Kadar Asam Laktat. Jurnal Ilmiah Peternakan. Vol 1(1):254-259.

Buckle, K. A., R. A. Edward, G.H. Fleet and M. Wooton, 1985. Ilmu Pangan (diterjemahkan oleh Purnomo, H dan Adiono). UI Press. Jakarta.

Godhia, M.L., dan Patel, N. 2013. Colostrum - Its Composition, Benefits As A Nutraceutical : A Review. Nutrition and Food Science. Vol. 1(1). Hal 37-47. 
Halim, C. N., dan Zubaidah, E. 2013. Studi Kemampuan Probiotik Isolat Bakteri Asam Laktat Penghasil Eksopolisakarida Tinggi Asal Sawi Asin (Brassica juncea). Jurnal Pangan dan Agroindustri. Vol 1 No 1. Hal 129-137.

Herawati, D.A., dan D.A.A. Wibawa, 2009. Pengaruh konsentrasi susu skim dan waktu fermentasi terhadap hasil pembuatan soygurt. Jurnal Ilmiah Teknik Lingkungan. Vol 1 No 2. Hal 48-58.

Kiełb, E. P., A. Zachwieja., E. Wojtas.,W. Zawadzki. 2018. Influence Of Nutrition On The Quality Of Colostrum And Milk Of Ruminants. Mljekarstvo. Vol 68. No 3. Hal. 169181.

Kunaepah, U. 2008. Pengaruh Lama Fermentasi Dan Konsentrasi Glukosa Terhadap Aktivitas Antibakteri, Polifenol Total Dan Mutu Kimia Kefir Susu Kacang Merah. Tesis. Universitas Diponegoro. Semarang.

Kurniati, T., Windayani, N., dan Listiawati, M. 2016. Total Asam Laktat, Protein, Karbohidrat, Dan Serat Whey Kefir Susu Sapi Berdasarkan Konsentrasi Starter dan Waktu Fermentasi. Seminar Nasional Biteknologi IV. Universitas Gadjah Mada. Yogyakarta.

Nihayah, I. 2015. Pengaruh Konsentrasi Starter Terhadap Kualitas Kefir Susu Sapi dan Pemanfaatannya Sebagai Penurun Kadar Kolestrol Darah Mencit. Skripsi. UIN Maulana Malik Ibrahim. Malang.

Oka, B., M. Wijaya., dan Kadirman. 2017. Karakterisasi Kimia Susus Sapi Perah Di Kabupaten Sinjai. Jurnal Pendidikan Tekonologi Pertanian. Vol 3 195-202.

Pogacic T., S. Sinko., S. Zamberlin., dan D. Samarzija. 2013. Microbiota of kefir grains. Mljekarstvo. Vol 63. No 1. Hal 3-14.

Standar Nasional Indonesia (SNI) 2897 : 2008. Metode Pengujian Cemaran Mikroba Dalam Daging, Telur Dan Susu, Serta Hasil Olahannya. Pusat Standarisasi Industri Departemen Perindustrian.

Standar Nasional Indonesia (SNI) No.01-2981-2009. Yoghurt. Pusat Standarisasi Industri Departemen Perindustrian.

Umam, M. F., R. Utami dan E. Widowati. 2012. Kajian Karakteristik Minuman Probiotik Pisang Kepok (Musa paradisiaca forma typical) dengan Menggunakan Starter Lactobacillus cidhopillus IFO13951 dan Bifidobacterium longum ATCC15707. Teknosains pangan. 1 (1) : 3-11.

Yusdar, Z., Yurliasni., Delima M., dan Diana E. 2013. Analisa Keasaman dan Total Bakteri Asam Laktat Yogurt Akibat Bahan Baku dan Persentase Lactobacillus casei yang Berbeda. Agripet. Vol. 13 No. 2 : 31-35.

Zaini, Z. O. F. 2016. Pengaruh Lama Fermentasi Terhadap Nilai pH, Total Asam, Jumlah Mikroba, Protein, Dan Kadar Alkohol Kefir Susu Kacang Kedelai (Glycine max (L) merill). Skripsi. UIN Maulana Malik Ibrahim. Malang. 